\title{
Meteorological table, for February 1810
}

\author{
Mr. Carey
}

To cite this article: Mr. Carey (1810) Meteorological table, for February 1810, Philosophical Magazine Series 1, 35:142, 160-160, DOI: 10.1080/14786441008563042

To link to this article: http://dx.doi.org/10.1080/14786441008563042

曲 Published online: 18 May 2009.

Submit your article to this journal 주다

LII Article views: 2

Q View related articles $₫$ 
160

Meteorology.

METEOROLOGICAL TABLE,

By Mr. Carey, of the Strrand,

For Felruary 1810.

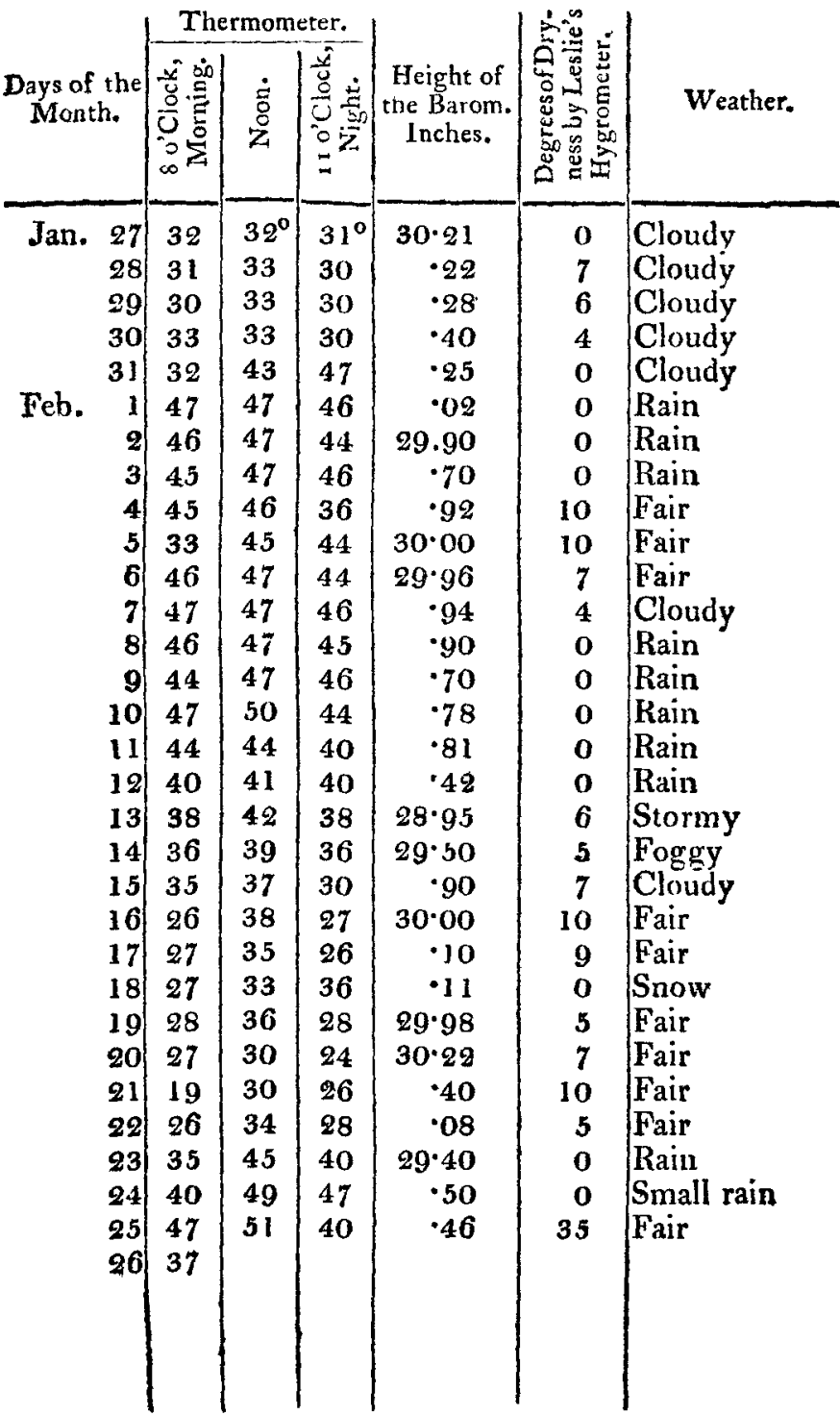

N.B. The Barometer's height is taken at one o'clock 